\title{
Four new cunaxoidine genera (Acari: Prostigmata: Cunaxidae) and the description of two new Neotropical species
}

\author{
JACOB DEN HEYER ${ }^{l} \&$ TATIANE M. M. G. de CASTRO ${ }^{2}$ \\ ${ }^{\prime}$ Setor de Zoologia, Departamento de Entomologia, e Acarologia Agrícola, Escola Superior de Agricultura "Luiz de Queiroz" \\ (ESALQ), Universidade de São Paulo, Piracicaba, São Paulo, Brazil, 13418-900. E-mail: jacob.den.heyer@gmail.com \\ South African address: Department of Zoology and Entomology, University of the Free State , P.O. Box 339, Bloemfontein. \\ Website: www.uovs.ac.za \\ ${ }^{2}$ Departamento de Fitossanidade, UNESP, Campus de Jaboticabal, São Paulo, Brazil, 14884-900. \\ E-mail: tatianemarie@yahoo.com.br
}

\begin{abstract}
In this paper the genus Cunaxoides Baker \& Hoffmann, 1948, as delimited by Den Heyer (1979a, 1981b), is revised and divided into five genera, viz. Cunaxoides Baker \& Hoffmann, Bunaxella gen. nov., Dunaxeus gen. nov., Funaxopsis gen. nov. and Qunaxella gen.nov.. Two new Neotropical species, Dunaxoides duosetosus and Qunaxella triasetosa are described and figured. Additional southern African material is reported. A key to the genera and species of the new genera of the subfamily Cunaxoidinae is provided.
\end{abstract}

Key words: Bdelloidea, Cunaxoidinae, four new taxa, taxonomy, identification key

\section{Introduction}

Koch (1838) was the first to describe a cunaxid with 3-jointed palps, indicating the difference from Cunaxa setirostris (Hermann, 1804), having five-jointed palps. He named this group Eupalus, not realizing that the name was already preoccupied by Gistl (1834). Baker \& Hoffmann (1948), realizing this, replaced the name Eupalus with Cunaxoides for all cunaxids with 3-jointed palps. Smiley (1975) was the first to separate a genus, Neocunaxoides Smiley, 1975, from this group. Den Heyer (1979a) separated further genera, viz. Pulaeus and Scutopalus. Smiley (1992) created two subfamilies of mites with 3-jointed palps, viz. Denheyernaxoidinae (a subfamily created to accommodate D. martini Smiley, 1992) and Paracunaxoidinae. The authors are of opinion that the scant and minor characteristics provided are only generic characteristics. We, therefore, disregard their subfamily status and only retain them as genera in the tribe Cunaxoidini. This action is indirectly supported by data obtained from Lin (2001) who combined Eupalus brevirostris Canestrini, 1885 on grounds of its morphology and chaetotaxy to Denheyernaxoides and provided more reliable data than did either Canestrini $(1885,1886)$ or Smiley $(1992)^{1}$.

The authors wish to accommodate in the key below all the genera of this subfamily but the genus Paracunaxoides Smiley, 1992 poses a problem. When the data (Smiley 1992) about the chaetotaxy of tibiae III and IV is considered, viz. a solenidion and 5 sts on tibiae III and a trichobothrium with 4 sts on tibiae IV, Paracunaxoides could be synonomous with Cunaxoides as indicated below. Not having seen the original

1. Lin (2001) in his table I provides the leg chaetotaxy of specimens of Denheyernaxoides brevirostris collected from various Chinese localities. It is interesting to note that the leg chaetotaxy of specimens from each locality differs from that of the other localities. Intraspecific variations? New species? 